\title{
Magic Realism, Minimalist Realism and the Figuration of the Tableau in Contemporary Hungarian and Romanian Cinema
}

\author{
Judit Pieldner \\ Sapientia Hungarian University of Transylvania (Miercurea Ciuc, Romania) \\ E-mail: juditpieldner@gmail.com
}

\begin{abstract}
The paper surveys two modes of representation present in contemporary Hungarian and Romanian cinema, namely magic realism and minimalist realism, as two ways of rendering the "real" in the Central Eastern European geocultural context. New Hungarian Film tends to display narratives that share the features of what is generally assumed as being magic realist, accompanied by a high degree of stylization, while New Romanian Cinema is more attracted to creating austere, micro-realistic universes. The paper argues that albeit apparently being forking modes of representation that traverse distinct routes, magic realism and minimalist realism share a set of common elements and, what this study especially focuses on, converge in the preference for the tableau aesthetic. The paper examines the role of tableau compositions and tableaux vivants in representative films of the Young Hungarian Film and the Romanian New Wave, namely Szabolcs Hajdu's Bibliothèque Pascal (2010) and Cristian Mungiu's Beyond the Hills (După dealuri, 2012). An excessive use of the tableau can be detected in both films, with many thematic connections, in subtle interwovenness with female identiy and corporeality performed as a site of traumatic experiences, upon which (institutional, colonial) power relations are reinscribed. The tableau as a figuration of intermediality performs the tension between the sensation of the "real" and its reframed image, and proves especially suitable for mediating between low-key realism and highly stylized forms. ${ }^{1}$
\end{abstract}

Keywords: magic realism, minimalist realism, intermediality, tableau, trauma. 


\section{Introduction. The Challenge of the "Real"}

The paper addresses particular ways in which contemporary Hungarian and Romanian cinema accounts for what is sensed and labelled as "the Eastern European reality." Since the fall of the communist regime in the Eastern bloc countries, the socio-cultural realities have undergone a sea-change and, at the same time, have preserved many aspects of the previous regime, resulting in a present, transitional state in-between "the post-communist condition" (Groys 2004)2 and "capitalist realism" (Fischer 2009). ${ }^{3}$ The past and present cultural landscape of these countries, marked by a general malaise following the euphoria of the regime change, arising from anomalies and incompatibilities - in the economic conditions, interpersonal relations and institutional systems, as well as due to the clash of global supermodernity and local, cultural and religious traditions -poses a challenge for all art forms that wish to come to terms with "the real" in this particular geocultural region, often perceived as "the Other" of (Western) Europe.

Contemporary Central Eastern European filmmaking, albeit obviously characterized by great generic, thematic and stylistic diversity, betrays a special appeal to the current socio-cultural realities with roots deep down in $\left(20^{\text {th }}\right.$ century) history. Whether in the shape of lavish, carnivalesque or austere, low-key cinematic representations, whether in fictitious or "ready-made" narratives, the haunting, almost obsessive presence of this inescapable, grotesque and tragicomic reality of Eastern European existence can be detected - or at least, a wish to grab the essence of its couleur locale is present. In general, Eastern European films are characterized by the embeddedness into the specific cultural context and space, which, in particular cases, cannot avoid the traps of superficial, self-exoticising misrepresentation, but which constitutes an integral part of the aesthetic constructedness and international recognition of a great number of auteur films. The critical-theoretical reception of contemporary Eastern European cinema shares the view that the relationship among body, image, memory and narrative results in characteristically different figurations of identity and subjectivity than in Western Europe or other parts of the world (Győri and Kalmár 2013).

2 “(...) to speak of the post-communist condition means giving serious consideration to the historical event that communism was and earnestly inquiring what traces still remain of communism and to what degree the experience of communism still marks our present reality but it also means asking why communism can at all be regarded as a mere historical intermission" (Groys 2004, 163).

3 "[Capitalist realism] is more like a pervasive atmosphere, conditioning not only the production of culture but also the regulation of work and education, and acting as a kind of invisible barrier constraining thought and action" (Fisher 2009, 16, emphasis in the original). 
Central Eastern European cinema reflects the identity of the region marked by a sense of inferiority and marginality in relation to Europe "proper," alongside an underlying skepticism towards the tendencies of globalization.

As special nuances on the palette of East Central European cinema, contemporary Hungarian and Romanian films are products - and reflections of the same "trauma culture," in the sense that many of their protagonists face crises, traumas or are on the way of processing traumas experienced in the recent communist past; they are trapped by identity patterns, places and institutions, and seek their identity by changing place, adrift in-between the East and the West (Király 2015). Andrea Virginás points at "a generational resemblance and a common sensibility" of the Romanian New Wave and the Hungarian Young/ New Film, in terms of the innovatory style or mode of representation; the stories told; the objects, sites, places and human bodies represented; and cinematic allegories created on screen (Virginás 2011, 132). Besides this shared thematic and discursive complexity, however, various modes of representation can be distinguished in the contemporary cinema of the two neighbouring countries, together with various stylistic-rhetorical particularities deemed characteristic in films signed by Hungarian and Romanian directors respectively. ${ }^{4}$

The present study is aimed at investigating two particular ways of rendering the "the real" in Young Hungarian Film and New Romanian Cinema, namely the magic realist tendency characterizing the former and minimalist realism related to the latter. Certainly, it would be far-fetched to link these modes of representation to distinct national cinemas, so much the more that the transnational aspect of film production is increasingly gaining ground. However, on a comparative basis, New Hungarian Film tends to display narratives that share the features of what is generally assumed as being magic realist, accompanied by a high degree of stylization, while New Romanian Cinema is more attracted to creating austere, micro-realistic universes. With significant exceptions on both sides, ${ }^{5}$ both discursive tendencies are inspired by and showcase the Eastern European sociocultural realities, albeit resorting to distinct modes of constructing narratives and cinematic imagery.

4 This study examines the specificities of Hungarian and Romanian cinema in terms of their discursive and rhetorical constructedness, ignoring further aspects of Eastern European cinema such as transnational production and domestic and international recognition, which are widely discussed in current specialist literature (see, for instance, Imre (ed.) 2012; Nasta 2013).

5 To bring counter-examples, the Hungarian Father's Acre (Apaföld, Viktor Oszkár Nagy, 2009) can be mentioned as a film akin in style to Romanian minimalist realism and the Romanian Somewhere in Palilula (Undeva la Palilula, Silviu Purcărete, 2012) as one sharing the characteristics of magic realism encountered in contemporary Hungarian films. 


\section{The Magic Realist Code in Young Hungarian Film}

In the Hungarian prose of the 1990s the revival of a mode of writing stemming from, and displaying "locally adapted" versions of, classical magic realism can be detected. In these writings the Eastern European geocultural landscape emerges as a hybrid zone in terms of mixed ethnicity, superimposition of old/premodern and new/post-communist life and identity patterns, and the juxtaposition of the ordinary and the extraordinary, which the narrative voice takes for granted and presents in its "already existing familiarity" (Jameson 1986, 304), in the spirit of magic realism where supernatural phenomena grow out organically from the depicted reality. A related tendency can be identified in Young Hungarian Film, especially among the directors belonging to the so-called Budapest Film School, whose productions are characterized by a penchant for creating visual universes similarly floating in-between the real and the unreal, allowing for excessive and carnivalesque modes of cinematic representation. With a new zest of storytelling and creativity, these cinematic narratives take us to the border zone of the real and the fantastic, where everyday absurdities come to life in form of ingenuous narrative twists and exhuberant spectacle. The films that qualify for the label "magic realist" in contemporary Hungarian cinema present the social, cultural and ethnic diversity of Central Eastern European existence through the clash of the trivial and the extravagant, of the local and the global, the taste of adventure against the backdrop of plain and bitter realities. In these films, magic realism may appear as a genre-shaping dominant, e.g. in Szabolcs Hajdu's films (Tamara, 2003, Bibliothèque Pascal, 2010), or as a quality adding to the visual rhetoric of films belonging to well-determined genres, e.g. in Diána Groós road movie entitled Vespa (2009). The expectation of a miracle, the fairy-tale like atmosphere characterizing some contemporary Hungarian film productions, such as the recent Liza, the Fox-Fairy (Liza, a rókatündér, Károly Ujj Mészáros, 2015), can be traced back to an existing tradition of visual stylization, abstraction and allegorical representation in Hungarian film history, in which Ildikó Enyedi's films, pervaded by elements of legends, fairy tales and myths, represent a special nuance. ${ }^{6}$ Thus,

$6 \quad$ In Ildikó Enyedi’s films, especially in the Magic Hunter (Bûvös vadász, 1994) and Simon Magus (Simon Mágus, 1999), "magic" is present both at a thematic level and as an inherent quality of cinematic representation. In this latter respect, the term "magic realism" was already used by Miklós Erdély, father-figure of the Hungarian Neo-Avant-Garde, with reference to the distinct quality of films made by Gábor Bódy, András Jeles, Béla Tarr and Péter Gothárin the 1970s and 1980s. Erdély tried to find the proper term for the new forms of expression through which these film directors sought - and found - ways to transgress the limits of filmmaking: "Some kind of realism... I don’t know: neorealism - isn’t is too used up? New neorealism - well, this is a 
an openness of contemporary Hungarian film towards the mythical, the legendary, the miraculous, towards alternative modes of storytelling can be detected, shaping a multilayered Central Eastern European mythological space marked by a strange compound of familiarity and foreignness.

Magic realism, one of the most important trends in $20^{\text {th }}$-century and contemporary fiction, ${ }^{7}$ is perhaps also one of the most controversial terms of literary theory. The juxtaposition of "magic" and "realism" in the collocation tends to be conceived as an oxymoron, where two opposite meanings are set against each other; however, as Alejo Carpentier used the term real maravilloso, magic is an inherent quality of reality, it emerges from reality; reality is in itself magical. According to Wendy B. Faris, the basic requirement for a literary work to be included in the canon of magic realism is "a preponderence of realism that includes irreducible elements of significant magic in it” (Farris 2002, 102). Tamás Bényei regards magic realism as a mode of writing and proposes to discuss magic realism in terms of the poetical and rhetorical specificities inherent in magic realist novels. He speaks of "double condensedness" ${ }^{\prime 8}$ characteristic of magic realism, at the level of the narrative code and that of figurative logic. Bényei contends that what is perceived as "magic" and "real" in a text is equally an effect created by the narrative. He emphasizes the performative, subversive and transgressive character of magic and outlines the figurative modality of magic realism in terms of: "ontological democracy" of the fantastic and the ordinary; subversion of boundaries; magic causality as a rhetorical trope; implementation of an analogous logic as opposed to the binary logic characteristic of rationalist thinking; the act of storytelling as the basic principle of magic realism; the importance of names and genealogy; hybridity, carnivalization; and ultimately, the poetics of excess that is present at all levels of the magic realist narrative (Bényei 1997).

Magic realism is essentially conjoined to socio-cultural realities where, despite the overwhelming impact of modernization, new technologies and the altered conditions of consumerism, there is an inherent premodern spirituality that these societies fall back on, accompanied by a simultaneous surrendering and resistance to the tendencies of globalization. Magic realism thus renders this amalgam of the premodern and the (post)modern, the local and the global, the central and the peripheral preserving a sense of in-betweenness and transitoriness.

little convoluted. Surely, some kind of realism... Magic realism?” (Erdély 1991, 195, translation mine, J. P.)

7 Tamás Bényei defines magic realism as an internationally spread mode of representation constituting an integrative part of the postmodern discourse (Bényei 1997).

8 In the Hungarian original: "kettős zsúfoltság" (translation mine, J. P.). 
The theoretical discourse around magic realism has been transferred to film as well. Frederic Jameson regards magic realism as "a possible alternative to the narrative logic of contemporary postmodernism" $(1986,302)$ and proposes to grasp the specificities of films creating poetic visual realities in terms of three representational codes that he calls history, colour and narrative. Jameson identifies this mode of representation in films that turn to recent historical events in close connection with the present, "history with holes, perforated history, which includes gaps not immediately visible to us, so close is our gaze to its objects of perception" (Jameson 1986, 303); colour, in Jameson's usage, implies the perceptual heterogeneity inherent in these films; and he perceives some kind of narrative reduction that allows for the seamless manifestation of visual experience, "to the benefit of a seeing or a looking in the filmic present" (Jameson 1986, 321).

Aga Skrodzka examines the role of magic realism in the Central Eastern European self-understanding and self-representation, as a transnational phenomenon. The author contends that the Central Eastern European condition, often perceived as provincial and behind the times, arrested in recurrent patterns of transitoriness, particularly favours this anti-realist, alternative and subversive mode of representation. With antecedents, among others, in the Czechoslovak New Wave, there is a growing tendency in contemporary East Central European cinema to render augmented realities through carnivalesque imagery and grotesque stylization, to resort to the hybridity of the magic realist mode as a response to the hybrid formations to be found in this region, in terms of ethnicity, life standards, identity patterns, space perceptions, etc. Aga Skrodzka is preoccupied with the East Central European socioeconomic conditions that provide a fertile soil for the proliferation of this popular trend and discusses films set mostly in rural or small-town environments which set the trivial, the private against grand history and reenvision reality by combining the real and the unreal, the familiar and the uncanny. Traditionally linked to similar sociocultural conditions, the author suggests, magic realism proves to be a strategy of responding to processes imposed by history that are much beyond the control of the petty individual: "Magic realism helps the provincial subject to make sense of the centre-enforced currents of history by introducing a pause in history, by exposing history as always a mixture of magic and logic. This strategy is especially important when people are victimised by a history that they can neither control nor fully comprehend" (Skrodzka 2012, 2). Magic realism associated with the East Central European zone can also be discussed in postcolonial terms, both temporally, as a territory 
recently liberated from under the Soviet ideological colonialism, and spatially, in terms of the "European colonization of its own margins" (Skrodzka 2012, 3).

\section{Minimalist Realism in New Romanian Cinema}

Another direction of dealing with the Eastern European realities can be identified in New Romanian Cinema. Interestingly, the Czechoslovak New Wave is regarded to be the common root of both trends: magic realism and a more stringent, less flamboyant mode of representation, the much discussed austere realism of contemporary Romanian film. The awareness of this common root leads to the recognition of a number of shared features of these distinct modes of representation, namely the carnivalesque style, the sensitivity to the East Central European absurdities, and above all, black humor and (self-)irony. In contradistinction to magic realism, the realist discourse of New Romanian Cinema much relies on the toolkit of observational documentarism, albeit applied in fictional narratives.

In the attempt of grabbing the specificity of the kind of realist discourse introduced by the new generation of Romanian filmmakers in the 2000s, the creator of which is regarded to be Cristi Puiu - he lies its foundations in his first film Stuff and Dough (Marfa şi banii, 2001) - Italian neorealism is often referred to as the film historical model for contemporary Romanian cinema, which did not have a similar neorealist period, as filmmaking in the 1950s was deeply compromised by the communist propaganda. Thus, historically, the realist mode may be regarded as a gap filling endeavour, however, its emergence cannot be limited to this diachronical aspect. Synchronically, as Radu Toderici (2014) points out, it can be placed in the wider context of European new realism of the 1990s, a kind of social realism employing peripheral characters who are emblematic for the social environment they belong to, and from the mid1990s on, the emphasized tendency of the Dogma '95 reinventing the cinematic discourse of cinéma vérité.

Cristi Puiu's hand-held camera, present in the unfolding of the events as a supplementary character standing for an observing viewpoint, stands closest to the new realism of European filmmaking. The impetus provided by Cristi Puiu launches a cinematic discourse that is heterogeneous in terms of a great diversity of form and evolving into several directions even within the productions of one single film director, but homogeneous in terms of the "ambiguity of represented reality and the author's distance from its own subject matter. For this reason, the new films often delimit themselves from the ethical or the political; it is not accidental 
that the major conflict within New Romanian Cinema has never been one related to subject matters but to style" (Toderici 2014, 149-150, translation mine, J. P.).

Although not all directors admit their categorization into any kind of film school (see Fulger 2006), ${ }^{9}$ there seems to be a consensus in the critical discourse to speak about contemporary Romanian movies in terms of "New Wave" and to characterize their mode of representation in terms of realism, micro-realism, verism and documentary style. Doru Pop surveys the terminological variations of New Romanian Cinema ("new wave," "post new wave," "new-new wave”), offers an extended as well as a short list of filmmakers ${ }^{10}$ and maps the common elements shared by films belonging to this trend, among which he mentions the penchant for documentary style filming; the preference for the long shot; realistic construction of space; unity of time and space; addressing direct and abrupt issues; authentic narratives; de-centred plots; breaking the "fourth wall;" contradiction between realism and theatrical representation; and recurrent iconographic references to religious Orthodox icons and masterpieces of art history in profanated reversals and mundane contexts (Pop 2010a).

Minimalist realism is a term widely used for New Romanian Cinema, grasping its specificities in terms of both subject matter (micro-realistic approaches with limited tendency of social allegorization; films concerned with "slices of life" of the recent past and the post-communist transition; Kammerspiel type family dramas, interpersonal conflicts, often banal, tragicomic situations placing in the centre the "everyman" - anti-heroes, provincial and petty figures - of contemporary Romanian society) and style (minimalist handling of time and space; lack of nondiegetic music; minimalist setting, mise-en-scène and character construction; understated acting; the employment of the fixed frontal camera position; the preference for long takes shot in real time; closeness to documentary style). In the chapter Less is More. Puiu, Porumboiu, Muntean and the Impact of Romanian Film Minimalism of her book on contemporary Romanian cinema, Dominique Nasta discusses Cristi Puiu, Corneliu Porumboiu and Radu Muntean as the three most important representatives of minimalist realism, with the significant contribution of the script writer and novelist Răzvan Rădulescu, who wrote many of the scripts of the Romanian art films directed in the 2000s. Minimalism primarily refers to low-key realism as the preferred filmmaking practice of these film directors, their films, however, are by far not minimalist in terms of their

9 Mihai Fulger includes the following film directors in the Romanian New Wave: Nae Caranfil, Thomas Ciulei, Alexandru Solomon, Cristi Puiu, Hanno Höfer, Cristian Mungiu, Florin Iepan, Radu Muntean, Cătălin Mitulescu, Tudor Giurgiu, Constantin Popescu and Corneliu Porumboiu. Cristi Puiu, Radu Muntean, Corneliu Porumboiu, Cristian Mungiu and Cătălin Mitulescu. 
affective potential, what is more, in any utilizable sense of the term, as Andrei Gorzo states prior to the release of Nasta's volume, polemically arguing against the superficial use of generalizing conceptual terms such as minimalism or realism in connection with New Romanian Cinema (Gorzo 2012).

\section{Convergences in the Tableau Aesthetic}

These two distinct modes of representation, the former aimed at excess and ornamentation, the latter at minimalism and austere realism, constitute alternatives to rendering the feeling - and trauma - of experiencing the Central Eastern European human condition. The innovatory style of both is evident, and a great bulk of films are preoccupied with the representation of dreary and dilapidated post-communist sites and of bodies as carriers of power relations; however, sensing the "real" seems to emerge in distinct templates.

I argue that albeit apparently being forking modes of representation that traverse distinct routes, the so-called magic realism and minimalist realism in Hungarian and Romanian cinema respectively, do share a set of common elements and, what this study especially focuses on, converge in the preference for the tableau aesthetic. I also argue that what is generally regarded as "minimalism" apparently aimed at sensing the real as an experience of immediacy, at fulfilling the spectator's "insatiable desire for immediacy," actually achieves this by creating a highly poetical and painterly universe, providing hypermediated experiences of "reality" according to the "twin logics of immediacy and hypermediacy" in Bolter and Grusin's sense of the terms $(1999,5)$. According to the theorists of remediation, "[h]ypermedia and transparent media are opposite manifestations of the same desire: the desire to get past the limits of representation and to achieve the real" $(1999,53)$. They base their argumentation on Derrida's concept of mimesis, conceived not objectively or ontologically, i.e. in the sense of a relation of resemblance between representation and the represented object, but intersubjectively, in the sense of the reproduction of the impression of resemblance in the perceiving subject: “'True' mimesis is between two producing subjects and not between two produced things" (Derrida 1981, 9, emphasis in the original). Bolter and Grusin highlight the interdependence of the immediacy and hypermediacy of experience by noting that even the most hypermediated media productions may strive for, or can result in, a sense of immediacy. Such instances of interconnectedness are what Ágnes Pethő $(2009,49)$ calls "hypermediated cinematic experiences of the real;" at the same time, she emphasizes the role of 
intermedial practices in the encounters of these - not at all antagonistic - modes of representation.

In her recent studies $(2014,2015)$ Ágnes Pethő points out the great diversity of the use of tableaux vivants and tableau compositions in contemporary Central and Eastern European cinema as autonomous images arresting the cinematic flow and emerging as sites of medial in-betweenness. While, according to Brigitte Peucker, the tableau vivant "figures the introduction of the real into the image the living body into painting - thus attempting to collapse the distance between the signifier and the signified" (Peucker 2007, 31), Ágnes Pethő contends that "the tableau does not attempt to merge representation with the real and to collapse the distance between signifier and signified, but emerges as a site for cultivating their distance in the opposition of sensual form and abstract meaning, moving image and static painting, live bodies in action and objects contemplated as a visual display, framing their intricate plays of in-betweenness" (Pethő 2014, 53). The medial in-betweenness of the tableau as an instance of "figured permeability" (Peucker 2007, 9) between the real and the image proves highly suitable for rendering the manifold aspects of in-betweenness profoundly characterizing the experience of the "real" in this region.

In order to illustrate the convergence of magic realism and minimalist realism in the figure of the tableau, I wish to refer to two films that stand for the paradigms under discussion, Szabolcs Hajdu's Bibliothèque Pascal (2010) and Cristian Mungiu's Beyond the Hills (După dealuri, 2012). Thematically, the two films share a set of common elements: they deal with unsettled - and unsettling - female fates experiencing and processing trauma (with more or less success), adrift between the East and the West and struggling to find their places between the desired intimacy and safety of private life and the abusing institutions they confront with, the brothel and the monastery respectively. Both films are preoccupied with female trauma and corporeality, exhibiting the female body as a carrier of the spirit of the place and of power relations. In a sense, magic is also a common element, albeit with opposite signs: in Hajdu's film it appears at the level of metadiegesis, Mona's act of storytelling being a means of "saving" the protagonist from death, whereas in Mungiu's film it is present at a diegetic level, irrational, magical thinking characterizing the institutions of the monastery and the hospital, as residues of medieval mentality, leading to the protagonist's decease. 


\subsection{Szabolcs Hajdu: Bibliothèque Pascal (2010)}

Szabolcs Hajdu's Bibliothèque Pascal is regarded in Hungarian criticism as the peak of the director's exhuberant magic realist style. Actually, the film combines austere realism, to be found in the frame story of the narrative, and magic realism, present in the embedded story, only to subvert and subtly relativize this diegetic antagonism by the end of the film. The story begins in the children's guardianship office, where the protagonist, Mona Saparu, has to give account of her recent past in order to gain back the custody of her child, as she has worked some time abroad and left behind her little daughter. Mona tells the story of her encounter with Viorel, the father of their future daughter, a man with the magical capacity of projecting inner dreams. They experience a fantastic common dream in which they wear traditional costumes. Viorel, wanted by the police, will be killed; their daughter, Viorica, inherits the magical capacity. In her attempt to find work abroad to raise her child, Mona falls victim to human trafficking, being sold as a prostitute. She gets to Bibliothèque Pascal, a bizarre luxury brothel in Liverpool, frequented by personalities of high rank, where the women are held in chambers and reenact literary figures such as St. Joan, Desdemona or Lolita. Mona is forced to reenact St. Joan first; then, as a punishment, she will be forced into Desdemona's role in latex suit. In the meantime, in her absence, her daughter is abused of by her aunt, who will make shows for money out of the child's dreams visible for others. The ultimate reality of Mona's being a sexual commodity turns into the realm of magic: the brass band led by Mona's father emerges from Viorica's dream and rescues Mona from the brothel right when she is almost asphyxiated in her role of Desdemona in bizarre circumstances. This is the story that Mona tells the official, but he rejects it, in his report he translates the magical story into a "real" one. However, he does not remain untouched by Mona's account and will finally give the custody to the mother. The film ends with the image of the mother and daughter in a cosy family scene, accompanied by the lofty tones of the Holy Night; however, it becomes obvious for the spectator that they are in an IKEA shop like simulacrum environment where they enact the familial scene; the camera also unveils the film director's presence, by this the film gains an additional framework, a metareferential touch.

It is at hand to interpret the film as an East Central European redemption story; the multiple narrative structure is built upon jigsaw puzzles of social realities (the fate of an unmarried mother, enforced migration and prostitution) combined with a retreat into the fantasy world with the implied ironical suggestion that 
salvation is only possible through "divine" intervention. As Bényei notes, the act of magic is invoked when there appears a gap, a fissure in our relationship with the world, and we try to fill the gap by resorting to some non-rational force or forum (Bényei 1997, 94). The diegesis of the film, with the implied metaleptic turn, that is, the border crossing between the "real" and the "magical," seems to confirm this argument.

Bibliothèque Pascal intersects the postcolonial discourse at several points. The film unveils the contemporary European scene as a heterogeneous territory carrying the residual traces of colonizing power relations. Mona's subjective narrative told from a double - ethnic and gender - minority position contrasted with the objective viewpoint of the official may be regarded as the repressed, silenced voice of the colonized; the marvellous element of her narrative grows out of, and seems to be compensating for, this subjected position. Mona, the enforced prostitute, and Pascal, the name giver of the Liverpool brothel, reproduce, again, a colonial relation. The Eastern European female emigrant's road intersects the path of the Albanian emigrant taking up his quarters in the Western world and basing his living upon the exploitation of other emigrants.

The film does fit into the magic realist paradigm: it contains "the irreducible element of significant magic" (Farris 2002, 102), that is, the magical capacity of projecting dreams shared by father and daughter, Viorel and Viorica, organically sewn into the texture of the film narrative, which confers playfulness at the level of the narrative and a high degree of stylization to the film, resulting in the "double condensedness" of magic realism. In line with the magic realist centeredness upon storytelling, here the act of narration is also of crucial importance: the embedded story, related by Mona to the guardianship official, is the product of a narrative transaction between man and woman evoking the archetype of the Arabian Nights (storytelling as the condition of survival, the implied magic of stories). The woman's surrealist story meets a sceptic male listener, with an additional contrast between the spoken and the written word, evoking the age-old debate between oral and written culture (their opposition is displaced in the closure, when the official refuses to record the heard story in writing, still, yields to the power of storytelling, noting down a negotiated "official" version of truth, which ultimately reverses the relationship between fiction and reality). The centrality of dreams (the father's and daughter's magical capacity of making their dreams visible for others) is also a magical realist characteristic, similarly to the importance and determining power of names (Mona's name predestines her to the enactment of Desdemona's role in the luxury brothel; in the case of father and daughter, the 
passing on of the name, Viorel-Viorica, entails the inheritance of the magical zest). The film also exhibits the transgressive and subversive character of magic (magic intervenes in situations of exposedness and entrapment) as a singular form of resistance to reality. Hybridization appears at several levels: as mixed language usage (there appear six languages spoken in the film, signaling uneven interpersonal relations and social disparities); at the level of ethnic belonging (the protagonist is half Romanian, half Hungarian, “jumi-juma” 'fifty/fifty,' as she says, reflecting the hybrid character of Transylvania, a contact zone with a mixed ethnic population; the owner of the luxury brothel is an emigrated Albanian, etc.); in terms of manifold cultural references (the diegesis of the film embraces Eastern and Western locations, juxtaposing dilapidated post-communist settings and exhuberant Western luxury places); as a generic mix (the women's transport by train, through the La Manche tunnel, to become prostitutes in the West evokes the tradition of slave narratives; the female protagonist's vicissitudes call forth the pattern of the road movie); and, last but not least, intermedial connections, the presence of the other arts (painterly, theatrical, literary references and their convergence in the utilization of the tableau).

In terms of form, I wish to argue that the heterogeneity of magic realism is taken over by the representational heterogeneity of the tableau. Whether present as tableau shots/compositions or tableaux vivants, ${ }^{11}$ tableau moments in film, conjoining painting, sculpture and theatre, stand for a sort of "intensified intermediality," as Brigitte Peucker suggests. ${ }^{12}$ The tableau, as a particular site of representational hybridity, arrests the flow of moving images, confers them a touch of perceptual difference, and initiates an especially fruitful dialogue between the "real" and its artistic rendition. The tableau aesthetic intersects the magic realist representational mode at several points. First and foremost, what connects them is the desire for excess. "Excess is the hallmark of the [magic realist] mode" (Zamora and Farris, 2005, 1); similarly, tableau moments confer the cinematic image a sense of saturation and density. Further on, the transgressive and

11 According to Ágnes Pethő, "the tableaux vivants proper (i.e. images imitating a particular painting or sculpture) together with other, similar techniques in cinema (static, tableau-like shots, inserts of photographs, and photographic reproductions of paintings) not only reflect on the connections between the visual arts, but, perhaps even more importantly, enclose and cultivate almost irreconcilable extremes: from a sensation of corporeality in pictures coming alive as embodied paintings to the distanciating effect generated by conspicuous artificiality and stylization" (Pethő 2014, 54).

12 "Tableau vivant moments in film set up a tension between the two - and three - dimensional, between stasis and movement, between the 'death' of the human body in painting and its 'life' in cinema. Further, because tableau vivant exists at the nodal point that joins painting, sculpture and theatre, its evocation in film is a moment of intensified intermediality" (Peucker 2007, 26). 
performative character of the magic realist representational mode also provides a contact surface with the transgressive and performative structure of the tableau. Whereas magic realism is transgressive in a narrative sense, in terms of crossing the boundaries of the "real" and the "magical," the tableau is transgressive in a medial sense. ${ }^{13}$ In addition, the "magical" finely sewn into the texture of the magic realist discourse is congruent with the enigmatic stance of the tableau in film: "The tableau in film is in itself an $a$-narrative figure which may however work its way into the fiction as metaphor, a secret: a representation that hides another. As Bonitzer points out, '[as] parody, homage or enigma, the shot-tableau always provokes a splitting of vision and gives the image a quality of a mystery, whether in the religious or in the detective-story sense'" ${ }^{14}$ (Vidal 2012, 120).

Szabolcs Hajdu's film under discussion much relies on the performative power of the tableau. It abounds in images serving to create visual excess on the screen; at several turns of the film the visual excess changes into haptic imagery, effect which is achieved through the intervention of tableau moments. The magic element inherent in the film narrative and the enigma posed by the tableau converge in the figure of the female protagonist. Mona's figure is repeatedly captured in long takes, from a fixed frontal camera angle, the protagonist looking into the camera, in a series of tableau compositions slightly reminiscent of Frida Kahlo's painterly autobiography (cf. Sándor 2014). The enigma is Mona herself; it is perhaps not accidental that Mona Lisa, the indecipherable enigma of the history of painting, also resounds in her name. Her cinematic portraits, inserted in the flow of her subjective narration, display the female figure who is simultaneously the subject matter and the agent of narration, the object and the owner of the gaze. This tension is perhaps most powerfully made perceivable through the protagonist's direct address; the tableau moments capture her as the object of the (male) gaze but which looks back and thus resists the panoptical gaze and her total reification as sexual commodity. [Figs. 1-2.]

The encounter of Mona and Viorel, rendered in a series of tableau compositions, is perhaps "the most magical" moment of the film. [Figs. 3-4.] Mona cannot leave Viorel, who has taken her hostage, because the man's dream comes to life in front

13 "I regard the cinematic tableau not only as a unit defined by certain fixed and flexible parameters, as a set of stylistic markers, but as a highly transgressive and performative structure. The tableau is always able to bring forth the intermediality of cinema as a productive in-betwenness, assigning the form of one medium (e.g. painting, photography, theatrical mise-en-scène) to act as a medium for a specific figure (the tableau shot) in the other medium (cinema)" (Pethő 2015, 41).

14 Reference: Bonitzer, Pascal. 1985. Décadrages. Cinema et Peinture. Paris: Cahiers du cinéma/ l’Étoile. Author's translation. 
of her eyes; the surface of the "real" is torn up and giving way to oneiric wonder. On a next tableau shot they sit face to face, wearing folk costumes of different ethnicity, Transylvanian and Spanish respectively, and their environment gets animated in the spirit of magic realist novels. This shot, together with the accompanying oneiric portraits of the woman and the man, represents a highly stylized, ornamental type of tableau, blending the "real" and the unreal, which may evoke in the spectator the densely decorated, gilt texture of Orthodox icons. As Katalin Sándor $(2014,83)$ writes, "[t]he projection of the dream, the uncanny in the animation of static pictures questions the delimitability of the living, the corporeal and the phantasmatically pictorial or oneiric, exposing Mona's narrative in which the imaginary, the irreal infuse or disrupt the real in a peculiar mode of interpreting the world." The tableau vivant presenting Viorel's execution at the seaside is rendered through a multiplied intertextual reference to La Belle Captive (Alain Robbe-Grillet, 1983) [Figs. 5-6], which reconnects to Édouard Manet's series of paintings The Execution of Emperor Maximilian (1867-68) in a Magrittean reframing. [Figs. 7-8.] Both films are concerned with metaleptic transgressions between dreams as inner, mental images and paintings/culturally coded images, which Mónika Dánél interprets as a metacinematic gesture, as the intimacy of the cinematic image capable of projecting the inner images of the spectators' private visual archives (cf. Dánél 2011, 2015).

The corporeality of the tableau, being traditionally concerned with "making real," provides a liminal surface where the female subject turns into an arrested image. Mona's figure challenges the representational layering of the tableau: besides evoking painting in the aforementioned manner, she is also connected to the theatre (she performs puppet theatre in a fair) and sculpture (in latex suit as Desdemona, rendered almost dead, in the last brothel scene). Mona's story is about the gradual loss of freedom, and the tableau moments play a key role in visually rendering this downward process. Mona finds herself in ever narrower spaces, from being held hostage by Viorel in the seaside cottage, through being taken prisoner, travelling by train in close confinement and being locked in a brothel room, to the final brothel scene where the space around her is restricted to the latex suit she is dressed in and the latex bag providing only a mouthful of air (cf. Varga 2015). The various hypostases of her captivity are rendered through tableau shots that suggest entrapment. The series of tableau compositions staging the rooms in the brothel evoke the "other" tradition of the tableau, that of pornographic tableau vivants. As the title of the film suggests, the Liverpool luxury brothel is conceived as a library - a heterogeneous place in itself - where 
prostitutes reenact canonical personalities of Western literature. St. Joan, Lolita, Pinocchio, Dorian Gray and Desdemona are all roles that evoke possessive relations and perform instances of reification of the Other. [Figs. 9-10.] These tableau shots stage the appropriation of the (female) body and perform the state of being enslaved within the image, enframed by the appropriated narrative/ dramatic text. The magical moment of the rescue - Mona's father emerging out of Viorica's dream, leading a brass band and liberating Mona from the brothel - is a narrative metalepsis set against this visual-corporeal entrapment.

The final scene of the film, Mona and Viorica "playing family" in an IKEA or KIKA shop, offers yet another tableau composition: they are boxed in an artificial environment which, for some moments, the viewer perceives as real but which then turns out to be only a simulacrum of reality. The genre image of harmonious domestic life accompanied by the tunes of the Holy Night blends pathos and irony; the tableau is then reframed by the presence of the director's figure, which is simultaneously a gesture of cinematic self-reflexivity and of relativizing the notions of "fiction" and "reality." In Hajdu's film magic realism rendered through the tableau aesthetic performs the deconstruction of "reality" and measures the power of words and that of images against each other. Mona's narrative will prevail in the end, by virtue of the atavistic power of words stemming from a "reality" that is, in essence, "magical."

\subsection{Cristian Mungiu: Beyond the Hills (După dealuri, 2012)}

In line with the credo of the New Romanian Cinema, Cristian Mungiu generally draws on stories that are profoundly embedded in social and geocultural realities. In interviews he emphasizes his interest in stories that he knows and his express intent of making his films as realistic as possible. In connection with his film entitled Occident (2002) he said: "I drew on real stories. [...] I can only tell stories that I know. I wanted it to be very realistic." (Mungiu qtd. in Nasta 2013, 186) The event that serves as the inspiration of his Beyond the Hills (2012), namely the exorcism of a young nun by an Orthodox priest and four nuns at the Monastery of Tanacu, ending in the novice's death, is a story that everybody knew in Romania in 2005, as it stirred great media scandal. The circumstances of the traumatic event divided public opinion at the time: for nonbelievers the event got contoured as an evidence of medieval mentality propagated by the Orthodox Church, adding to the negative image of Romania at the threshold of entering the European Union; within the group of believers, some had to reconsider 
their relation with the Orthodox Church, others put the blame on its members implied in the event. The event generated further interpretations: as a reaction to the strong opinions formulated in the media, the journalist Tatiana Niculescu Bran published a nonfictional novel entitled Deadly Confession (Spovedanie la Tanacu, 2006), written with the claim of documenting the real life events. In spite of the intent of documenting the events, there is a touch of subjectivity characterizing Bran's account of the events; the "close reading" of the novice nun's tragical story is completed with a suggestive and dramatic representation of her being possessed, with the presentation, by resorting to literary devices, of the parallel world unfolding in her mind inhabited by her devils inside. Thus, to a good extent, subjectivity overwrites the nonfictional stance claimed on the cover of the book. The book was written, as the author said, with the intent of correcting the media image of the event.

The reception history of the Tanacu event continued in 2007 with a theatrical adaptation, the performance of The Andrei Şerban Travelling Academy entitled Deadly Confession/Spovedanie la Tanacu, the result of cooperation between Andrei Şerban and Tatiana Niculescu Bran, presented on the stage of the La MaMa Theatre in New York and at the Odeon Theatre in Bucharest respectively. The stage performance also aimed at staying close to the "real" event, however, the documentary purport was, again, blurred by symbolic elements and by the implied aim of exercising an emotional impact upon the audience. In the following year Tatiana Niculescu Bran published another book, entitled Judges' Book (Cartea Judecătorilor, 2008), which deals with the trial of the priest and the four nuns implied in the ritual of exorcism. As it can be seen, artistic representations join in the debate stirred by the media, transforming it into a field of investigation and formulating possible artistic responses. There is a struggle for getting closer to truth in the various transmediations, the "real" being "there" as a puzzle awaiting to be solved but at the same time evaporating behind the generic-stylistic conventions of distinct artistic media. ${ }^{15}$ The reception history of the Tanacu event, encompassing literature, theatre and also film through Mungiu's contribution, truly dramatizes a process of signification in which the "real" as the ultimate signified becomes unattainable in the Derridean sense of the infinite regress of the "real."

In 2012 the release of Mungiu's film reopened the field of discussion. The film relies on the previous literary and theatrical transmediations but cuts back

15 For a detailed analysis of the reception history of the Tanacu event, with a special focus on its artistic transmediations, see Iftene (2013). 
the subjective and mystical aura created around the Tanacu event. It renders the "real" behind the veil of fiction by changing the names of the protagonists (the victimized nun, Irina Maricica Cornici appears as Alina and her childhood friend, Paraschiva, is named Voichița) and also by locating the scene of action in a fictitious place, referred to in the title as a nowhere place, without exact coordinates but imaginable anywhere, similar to the story which becomes emblematic of the spatio-temporal and spiritual confinedness of particular social layers in Romania. Besides this spatial (non-)reference, the "beyond" in the title may have further associations: in the context of the transmedial search for truth, it may be read as an imperative that urges us to look "beyond" the facts and restage the happenings at a more universal level; it may also be interpreted as bearing transcendental, metaphysical connotations, which become the target of cinematic rendition.

The story is "simple:" Alina, an orphan girl returning from Germany where she has been working, visits her childhood friend, Voichița, who is now a nun in a monastery from Moldova, a place ripped from time and space, "beyond the hills," with the intention of convincing her to go with her to Germany. However, Voichița's onetime affection towards her has turned into profound religiousness. Although Voichița has a passport made, she cannot make up her mind to leave with Alina, she sticks to the monastery, which triggers Alina's alienation from the place. The film suggests that Alina is burdened by past experiences (especially the affection beyond friendship between the two girls which used to compensate for the lack of love in the orphanage) that are interpreted as "sins" within the monastery and she is urged to confess. Alina shows the first signs of deep distress; after the first crises she is hospitalized and then taken back to the monastery. She does not find her place there, she is taken back to her foster parents but there she faces the situation that she has been "replaced" with another girl; she decides to go back to the monastery. When she realizes that there is no place for her anywhere (Voichița can no longer love her the way she used to because she has devoted herself to God; her family has virtually disowned her; the monastery has deprived her of much of her saved money on behalf of the compulsory "contribution to the monastery," and although she has confessed, the symptoms of her illness return), her crises become so wild that at a certain point she is tied (with the rope of the bell and the chain of the dog), then subjected to the process of exorcism, during which the priest reads Saint Basil Prayers of Exorcism above her chained body in order to relieve her from the devil inside. In the process of weakening "the evil within her," she does not resist and the priest and the nuns 
awake realizing that they have committed a crime. The film ends with their being taken to the police.

Mungiu's film translates the Tanacu event into the troubled relationship between the two female protagonists whose intimate bond has been disturbed by the evolution of their destiny, adrift among the non-places ${ }^{16}$ and heterotopias of contemporary society that provide only transitory patterns of identity (orphanage, Western workplace, monastery, foster parents' home, hospital, police). In this respect, Beyond the Hills reverberates with 4 Months, 3 Weeks and 2 Days (4 luni, 3 săptămâni şi 2 zile, Cristian Mungiu, 2007) as the story of a friendship facing a moral test; this time the events are set in the post-communist period, marked by the institutional legacy of communism and by the legacy of the Middle Ages in terms of mentality. It is the institution of religion, together with the medical institution, that victimize the protagonist, outlining a moral scheme in which no one is to be blamed, everyone has their own truth. An intimate family atmosphere at the monastery, caring benevolence that surrounds Alina - still, her death is deemed as murder. While nobody can be individually blamed for, the protagonist seems to be victimized by a whole social apparatus, an accumulation of individual irresponsibilities leading to her death. In the light of the girl's unusual and mysterious pathological case the deficiencies of both the Orthodox Church and the Romanian medical system are revealed. In the distorted mirror of Alina's illness, the film points at the transitory state and disfunctionality of Romanian social organization.

The film continues the minimalist mode of representation characteristic of Romanian New Wave and of Mungiu's earlier films. The almost obsessive use of long takes, claustrophobic shots and fixed frontal camera angle creates the effect of visual entrapment and renders a slice of Romanian "reality" stuck in a rural, premodern way of life and breathing medieval mentality. Life in the monastery is centred on the "father figure" of the priest; Alina's case displaces his unwavering authority and confronts the religious micro-community with its own limits. The film, however, does not exercise direct criticism, but rather entrusts the spectator with this task, a characteristic which is also in line with the discourse of the New Romanian Cinema. Instead of exercising direct moral judgement, the film creates painterly images, powerful enough to turn the moving image into a contact zone of unsettling intermedial encounter.

16 "If a place can be defined as relational, historical and concerned with identity, then a space which cannot be defined as relational, or historical, or concerned with identity will be a nonplace” (Augé 1995, 77-78). 
The film betrays the penchant for iconographic references, for "imaginary symbolism" that Doru Pop lists among the features of the Romanian New Wave and identifies especially in Cristian Mungiu's and Corneliu Porumboiu's film art. Their cinematic practice powerfully relies on the utilization of cinematic references to masterpieces of the history of painting, alongside compositions in the spirit of Orthodox icons in profane contexts, reversing their original signification and displaying patterns of cultural-spiritual emptiness or emphasizing the grotesque-ironical aspect of the particular situation (Pop 2010a). Mungiu's great achievement in this film is that he chooses to relate a story that thematically motivates the introduction of references to Orthodox religious icons, upon which a subtle metathematic, even metacinematic reference will be layered.

Beyond the Hills abounds in tableau compositions; it is perhaps not exaggerating to say that it renders the story virtually through tableau shots. Alina's arrival at the nowhere place of the monastery is rendered in a landscape tableau shot, in which the tiny figures of the two girls appear against the vast panorama of the landscape, with the village and mountains in the background, suggesting the power of the place that swallows the powerless individual doomed to become one with the place. Later, Alina and Voichița are represented indoors, sitting on the bed in Voichița's room, at the outset of Alina's staying in the monastery; she hopes that they can return to their former intimacy, but Voichița has distanced from her; the two-figure tableau composition makes perceivable the feeling of loss and foreshadows Alina's downturn. Actually, both the open-air and the interior tableau shots stage the heroines' confinedness and entrapment. [Figs. 11-12.]

The almost obsessive utilization of the tableau opens up an intermediary space between cinema and painting, the latter providing not simply the painterly quality of moving images but, much more significantly, the impetus for evoking the invisible "beyond" the visible. And this is the point where the thematic layer of the film resonates with a metacinematic layer, namely the - old and new - theoretic discourse of the "real" in cinematic representation. The film goes "beyond" the concerns of realistically representing a real event and doing justice in moral terms, and engages in a discussion, held over the decades of film history, about the relation between the visible and the invisible, situated at the core of the metaphysics of the moving image. The presence of painterly references raises in the spectator this metaphysical expectation; the film masterfully counterpoints this by simultaneously pointing at and withdrawing the metaphysical aura of the images, resulting in a subtle game of deconstruction, showing the presence as absence, turning the invisible into a metaphysical hole. The tableau shots 
in Mungiu's film constitute intermedial figurations where the immanent, the material, meant to bring forth the transcendental, the spiritual, becomes the signifier of absence. It is this absence, the lack of divinity, the regress of the transcendental signified that is inscribed in the profanated appropriations of cultic images of religion and art.

The majority of tableau shots in the film, finely woven into the texture of realist representation, reconfigure the iconography of Orthodox icons, creating triadic compositions reminiscent of the classical icons. The Orthodox icon is a sacred image, the portrait of Divinity; its name suggests the idea of the perfect "copy" of the image of Christ. The primeval model of the icon is the Veil of Veronica as the first instance of material representation of the face of Christ. In the Orthodox religious practice, the icon serves to mediate between the earthly and the otherworldly as the image of another reality that is more real than the earthly world. Thus, it is at hand to create the analogy between the icon and the cinematic image, which carries on itself the imprint of reality as the Veil of Veronica according to André Bazin's realist aesthetic. ${ }^{17}$

In the practice of New Romanian Cinema, the iconography of the Orthodox icon is intensely utilized and subverted in profane contexts. In Beyond the Hills, the series of tableau shots, thematically grounded in the religious context, are not only restricted to the genre images of life in the monastery but also extend to slices of life outside it, and offer a great diversity of the triadic composition, rendering more and more grotesque representations, replacing religious iconographic elements with everyday objects (e.g. a grid of eggs, a huge teddy bear) which become markers of the profane that seeks its way into the sacred, documenting the process of Alina's downfall. [Figs. 13-16.] Above the doctor's seat in the hospital room there hangs a triptych-like composition which consists of an Orthodox icon, a landscape painting and a reproduction of Mona Lisa, the ironic effect being amplified by the "Holy Trinity" of those present: the male doctor dressed in white in the centre, facing the camera, and the two female figures, Voichița and the prioress, dressed in black, facing him, and turning their back to the camera. This "mundane trinity" confronts Alina's "helpers," the - similarly patriarchal - medical system, the Orthodox Church as well as her friend, and mocks at their inertia when faced with Alina's case. [Fig. 16.]

17 As Doru Pop expounds on this analogy: "In the same way the icons 'capture' an essence that is beyond the reality of this world and the materiality of the support, cinema's essence is beyond the reality it needs in order to transmit a message. Like the icon, cinema is projected on a surface - the screen is only an intermediary between the viewer and the reality (never present) that is viewed" (Pop 2010b, 82). 
Besides the great number of tableau shots evoking the Orthodox icon, and above all, the Trinity, in mundane configurations, suggesting a kind of predeterminedness by the representational tradition, the film abounds in various types of tableau compositions. Such is the group representation of the priest and nuns emotionally reacting to the happenings that disturb the peaceful life in the monastery, created in the spirit of Caravaggesque dramatism, making use of the chiaroscuro effect. Further on, the tableau compositions of table scenes should be mentioned, devised, again, in line with the iconography of Orthodox icon painting. New Romanian Cinema abounds in table scenes; let me only refer here to the supper sequence of Mungiu's 432, lasting for more than six minutes, a real tour de force which makes use of the off-screen space and simultaneously places the protagonist visually in central position and aurally at the periphery (cf. Nasta 2013). Similarly, in Beyond the Hills, the tableau compositions representing table scenes also perform this simultaneously central and peripheral position of Alina's, showing the germ of her gradual alienation from the religious community, especially the one which shows the priest positioned in the centre of the image in the foreground, turning his back to the camera, accompanied by the nuns on either side; Alina is positioned off-frame,$^{18}$ which is indicative of her exclusion as the "other" of the patriarchal community. The crowded composition characterizing the film's table scenes may evoke in the spectator the famous representation of The Last Supper created by one of the leading $17^{\text {th }}$ century Russian icon painters, Simon Ushakov. [Figs. 17-18.]

Finally, the performative character of the tableau should be mentioned. The excessive use of tableau compositions performs a predetermined "reality," suggesting entrapment and stigmatizing the female body. In one of the final sequences of the film, Alina's living corpse, at the threshold of death, is isolated in a separate building in the yard of the monastery. [Fig. 19.] The tableau composition that shows Alina's lying body following the process of exorcism, unchained by Voichița, then left alone and arrested in a long take, represents the body in-between life and death, in a spiritual vacuum. Thus, the exorcized nun's story, relating the quest for identity against the backdrop of the patriarchal order of the Orthodox Church, turns into an unsettling story of sacrifice.

18 Ágnes Pethő distinguishes between "off-screen" and "off-frame" as follows: "the tableau shot is usually remarkable not only for what it boxes in but also for what it boxes out. As opposed to the notion of 'off-screen,' which denotes according to Pascal Bonitzer (2000) an imaginary/fictional dimension, 'off-frame' can be conceived as an actual, material space, outside the cutting edge of the frame encompassing both the extension of the diegetic world and the space of the spectator facing the screen" (Pethő 2015, 51). 


\section{Conclusions}

To conclude, there are many thematic elements that connect the two films discussed above, belonging to the magic realist and minimalist realist codes respectively (e.g. the traumatized female body; the implosion of female identity and individuality within exploiting institutional framework; spatial and temporal entrapment; the presence of magic; the power of the spoken word, albeit with opposite signs). In both cases the medium of manifestation of the magical is the female body. In the light of each other, the two films perform the dialogue of views upon corporeality distinctly coded in a cultural sense (the female body conceived along the "literary canon" of perverted sexual fantasy in Bibliothèque Pascal, and in terms of religion infused with beliefs and superstitions in Beyond the Hills). In their turn, both films subvert the meanings of "magic" and "reality" and display the Central Eastern European region as a space characterized by the incursion of magic into the "real," where reality in itself surpasses any kind of magic or fiction. As Aga Skrodzka suggests, "[w]hether the cinematic vision is a compensatory ideal or a hyperbolic dystopia, it is crucial to see the connection between the two; both are ways of reimagining the unsatisfactory reality" $(2012,24)$.

Ultimately, what this paper has aimed to suggest is that, perhaps more significantly, the figurativity of the tableau, albeit with distinct uses, is what relates the two modes of representation, not as each other's opposites but as alternatives of accessing and deconstructing the same "reality," the same unspeakable "trauma culture." In Szabolcs Hajdu's Bibliothèque Pascal the presence of tableau compositions and tableaux vivants translates the notion of magic realism, difficult to grasp in formal terms, into the materiality of the cinematic image, the discursive excess of magic realism into the visual excess of the moving image; in Cristian Mungiu's Beyond the Hills, the tableau becomes the signifier of absence in the context of minimalist realism. In a way, both can be translated into the excess of the moving image that renders the absence experienced at the level of the "real;" they stand for alternatives of creating profoundly affective images at the level of spectatorial reception. As this paper has tried to demonstrate, the tableau as a figuration of intermediality, as one of the various aesthetic practices, rooted in the tradition of artistic representation, that testify to "pleasure of movement between the real and the image" (Peucker 2007, 11), performs the tension between the sensation of the "real" and its reframed image, and proves especially suitable for reconciling distinct representational modes in contemporary cinema, for mediating between low-key realism and highly stylized forms. 


\section{References}

Augé, Marc. 1995. Non-Places: Introduction to an Anthropology of Supermodernity. London and New York: Verso.

Bényei, Tamás. 1997. Apokrif iratok. Mágikus realista regényekról. [Apocriphal Documents. On Magic Realist Novels.] Debrecen: Kossuth University Press.

Bolter, Jay David and Richard Grusin. 1999. Remediation. Understanding New Media. Cambridge, Massachusetts and London: The MIT Press.

Bonitzer, Pascal. 1985. Décadrages. Cinema et Peinture. Paris: Cahiers du cinéma/ l'Étoile.

Dánél, Mónika. 2011. Kihordó természet, kultúra, nők - belső gyarmatok. Kortárs magyar filmek posztkoloniális olvasatai. [Surrogate Nature, Culture, Women - Inner Colonies. Postcolonial Readings of Contemporary Hungarian Films.] Metropolis vol. XV. no. 3: 56-65.

Dánél, Mónika. 2015. A megjelenítés gesztusai, (belső) képek valósága Hajdu Szabolcs filmjeiben. [The Gestures of Representation, the Reality of (Mental) Images in Szabolcs Hajdu's Films.] Prizma no. 13: 42-49.

Derrida, Jacques. 1981. Economimesis. Diacritics vol. 11. no. 2: 2-25.

Erdély, Miklós. 1991. „A kalocsai előadás.” Múvészeti írások. [“Lecture in Kalocsa." Essays on Art.] Budapest: Képzőmúvészeti Kiadó.

Farris, Wendy B. 2002. The Question of the Other: Cultural Critiques of Magical Realism. Janus Head vol. 5. no. 2: 101-119.

Fisher, Mark. 2009. Capitalist Realism. Is There No Alternative? London: Zero Books.

Fulger, Mihai. 2006. „Noul val” în cinematografia Românească. [The "New Wave” in Romanian Cinematography.] Bucureşti: Art.

Gorzo, Andrei. 2012. Lucruri care nu pot fi spuse altfel: un mod de a gândi cinemaul, de la André Bazin la Cristi Puiu. [Things That Cannot Be Said in Any Other Way: A Way of Thinking Cinema, from André Bazin to Cristi Puiu.] Bucureşti: Humanitas.

Groys, Boris. 2004. The Post-Communist Condition. In Who If Not We Should at Least Try to Imagine the Future of All This?, eds. Maria Hlavajova and Jill Winder, 163-170. Amsterdam: Artimo.

Győri, Zsolt, Kalmár György eds. 2013. Test és szubjektivitás a rendszerváltás utáni magyar filmben. [Body and Subjectivity in Post-Communist Hungarian Cinema.] Debrecen: Debrecen University Press. 
Iftene, Daniel. 2013. Truth through the Meaning Glass: Tanacu in Literature, Theatre and Film. Studia Universitatis Babeş-Bolyai, Dramatica vol. LVIII. issue 1: 77-88.

Imre, Anikó ed. 2012. A Companion to Eastern European Cinemas. Malden, MA - Oxford - Chichester: Wiley-Blackwell.

Jameson, Frederic. 1986. On Magic Realism in Film. Critical Inquiry vol. 12. no. 2: 301-325.

Király, Hajnal. 2015. Leave to Live? Placeless People in Contemporary Hungarian and Romanian Films of Return. Studies in Eastern European Cinema vol. 6. no. 2: 169-183.

Nasta, Dominique. 2013. Contemporary Romanian Cinema. The History of an Unexpected Miracle. London and New York: Wallflower Press.

Pethő, Ágnes. 2014. The Tableau Vivant as a "Figure of Return” in Contemporary East European Cinema. Acta Universitatis Sapientiae: Film and Media Studies vol. 9: 51-76.

Pethő, Ágnes. 2015. Between Ansorption, Abstraction and Exhibition: Inflections of the Cinematic Tableau in the Films of Corneliu Porumboiu, Roy Andersson and Joanna Hogg. Acta Universitatis Sapientiae: Film and Media Studies vol. 11: 39-76.

Peucker, Brigitte. 2007. The Material Image: Art and the Real in Film. Stanford, California: Stanford University Press.

Pop, Doru. 2010a. The Grammar of the New Romanian Cinema. Acta Universitatis Sapientiae: Film and Media Studies vol. 3: 19-40.

Pop, Doru. 2010b. The Iconoclasm of the New Romanian Cinematographers. Ekphrasis no. 2: 77-93.

Sándor, Katalin. 2014. Corporeality and Otherness in the Cinematic Heterotopias of Szabolcs Hajdu's Bibliothèque Pascal (2010). Ekphrasis vol. 12. no. 2: 79-92. Skrodzka, Aga. 2012. Magic Realist Cinema in East Central Europe. Edinburgh: Edinburgh University Press.

Toderici, Radu. 2014. Noul Cinema Românesc şi realismul european al anilor '90. [New Romanian Cinema and the European Realism of the 1990s.] In Politicile filmului. Contribuții la interpretarea cinemaului românesc contemporan [The Politics of Film. Contributions to the Interpretation of the Romanian Contemporary Cinema], eds. Andrei Gorzo and Andrei State, 131-150. ClujNapoca: Tact. 
Varga, Balázs. 2015. Terek és szerepek. Tér és identitás Hajdu Szabolcs filmjeiben.

[Spaces and Roles. Space and Identity in Szabolcs Hajdu's Films.] Prizma no. 13: 4-13.

Vidal, Belén. 2012. Figuring the Past. Period Film and the Mannerist Aesthetic. Amsterdam: Amsterdam University Press.

Virginás, Andrea. 2011. New Filmic Waves in Hungarian and Romanian Cinema: Allegories or Stories about Flesh? Acta Universitatis Sapientiae: Film and Media Studies vol. 4: 131-141.

Zamora, Lois Parkinson and Wendy B. Faris. 2005 [1995]. Magical Realism: Theory, History, Community. Durham and London: Duke University Press.

\section{List of Figures}

Figures 1-2. Direct address in Bibliothèque Pascal (Szabolcs Hajdu, 2010).


Figures 3-4. Ornamental-oneiric tableau shots in Bibliothèque Pascal.
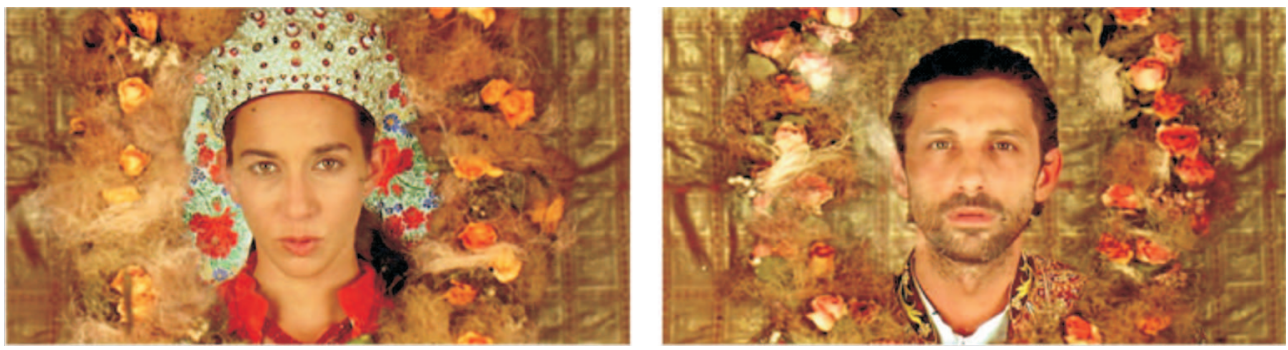
Figures 5-6. Intertextual dialogue: La Belle Captive (Alain Robbe-Grillet, 1983) and Bibliothèque Pascal.
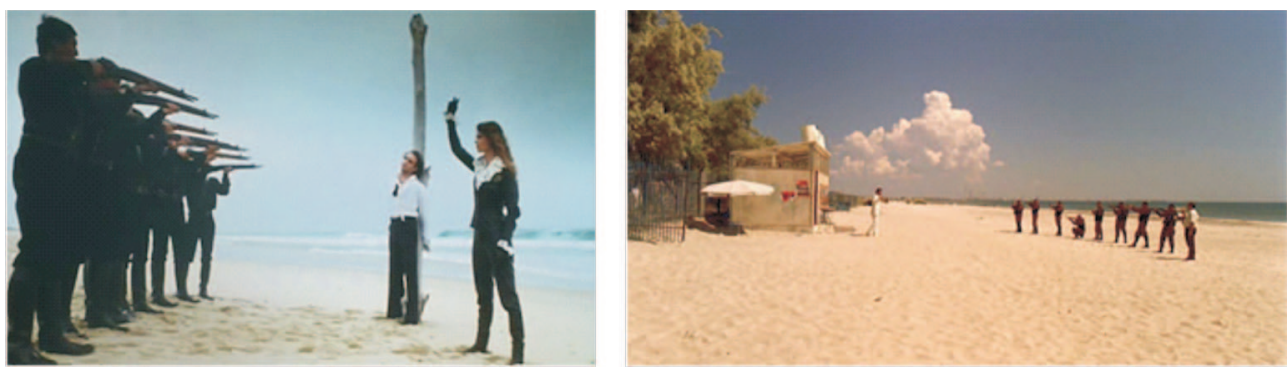

Figures 7-8. References to Manet and Magritte in La Belle Captive (Alain RobbeGrillet, 1983).
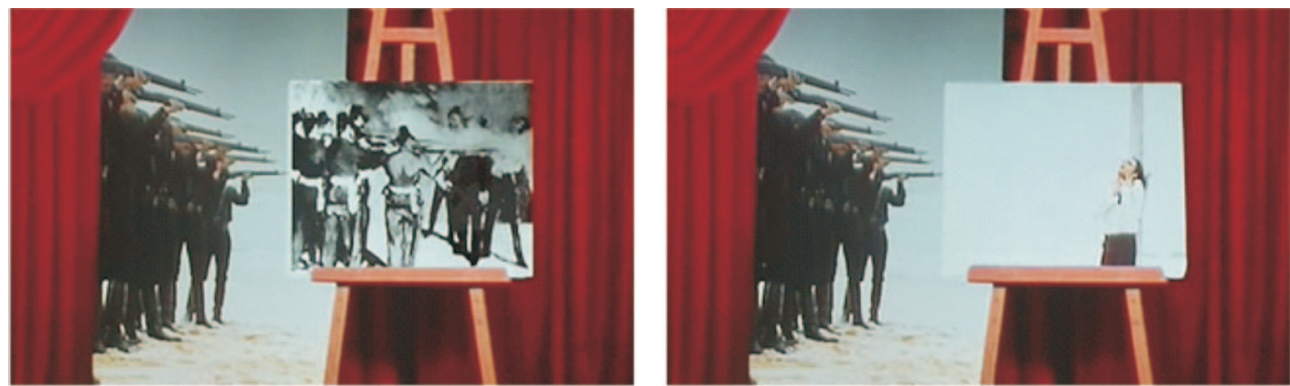

Figures 9-10. Tableau shots evoking brothel roles in Bibliothèque Pascal.
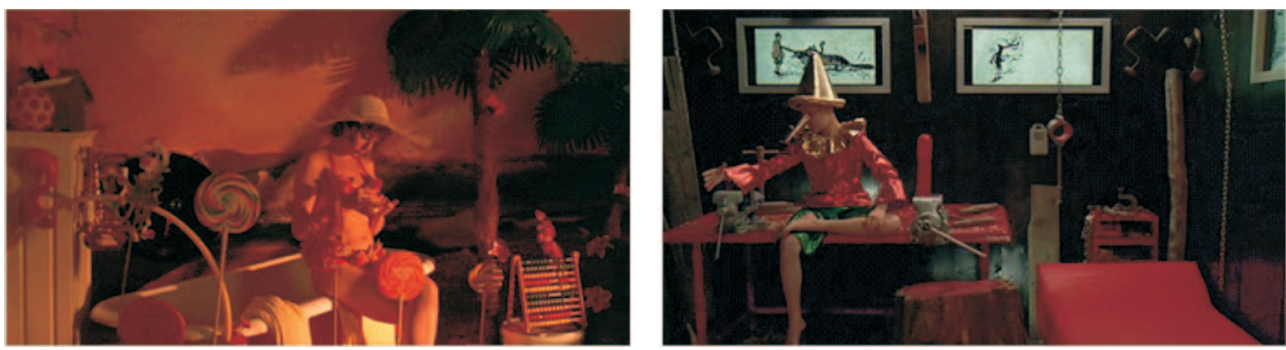

Figures 11-12. Open-air vs indoor spaces, tableau shots in Beyond the Hills (După dealuri, Cristian Mungiu, 2012).
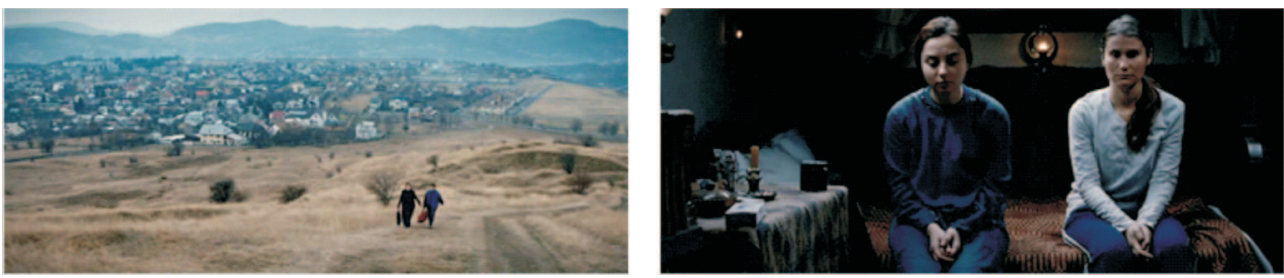
Figures 13-16. Triadic compositions in Beyond the Hills.


Figures 17-18. Tableau composition in Beyond the Hills. Simon Ushakov: The Last Supper (1685)
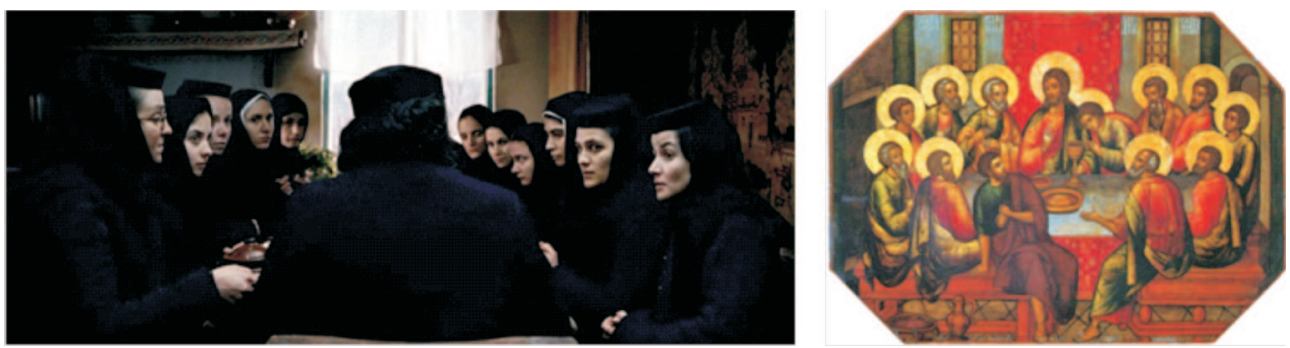

Figure 19. Alina's living corpse in Beyond the Hills.

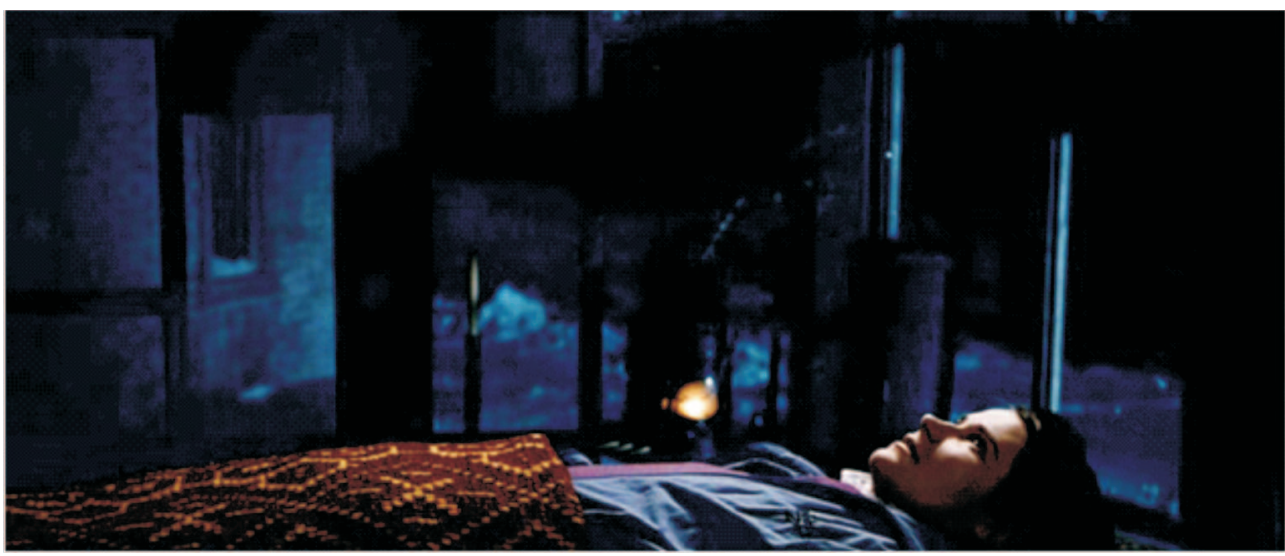

